\title{
Synanthropic flies of Asir Province, southwest of Saudi Arabia
}

\author{
M.A. Kenawy, ${ }^{1}$ H.A. Al Ashry, ${ }^{2}$ M. Shobrak ${ }^{3}$ \\ ${ }^{1}$ Department of Entomology, Ain Shams University, Cairo, Egypt; ${ }^{2}$ Environmental Balance Co., \\ Alrawdah District, Jeddah, Saudi Arabia; ${ }^{3}$ Biology Department, Science College, Taif University, \\ Saudi Arabia
}

\begin{abstract}
A survey of synanthropic flies was carried out in 11 slaughter houses in 8 localities representing different altitudes in Asir. Flies were sampled twice a month from December 2008 to November 2009 by Final Flight Fly Traps. A total of 11,737 flies consisting of 19 species, belonging to 7 families were collected, of which those of family Muscidae predominated (94.88\%) followed by Calliphoridae (3.12\%), Sarcophagidae (1.22\%) and Fanniidae (0.55\%). The other 5 families (Piophilidae, Oestridae, Phoridae, Ulidiidae and Lonchaeidae) totally represented $0.79 \%$. Of the identified species, Musca domestica was predominant $(94.26 \%)$ followed by Lucilia sericata (1.51\%), Sarcophaga carnaria (1.01\%), Chrysomya albiceps (0.67\%), Fannia canicularis (0.55\%), Chrysomya marginalis (0.54\%), Muscina stabulans (0.52\%), Calliphora vicina (0.39\%), Wohlfahrtia nuba (0.14\%), Megaselia scalaris (0.08\%), Lonchaea sp. (0.06), Bercaea cruentata (0.05), Ophyra sp. and Oestrus ovis (0.04\% each), Atherigona sp., Piophila casie and Physiphora demandala (0.03\% each) and Parasarcophaga ruficornis (0.01). Flies altogether were more common (16 spp., 84.21\%) and abundant (36.45 fly/trap) in highlands than in the other altitude levels. The highlands were found with the maximum Simpson $(1-\mathrm{D}=0.18)$ and Shannon $(\mathrm{H}=0.49, \mathrm{P}<0.001)$ diversity indices. Likewise, the highest density of $M$. domestica was in the highlands $(\mathrm{P}<0.05)$. Regression analysis confirmed that house fly density was directly related to the altitude level $(\mathrm{P}<0.05)$. In all altitude levels,
\end{abstract}

Correspondence: Mohamed A. Kenawy, Department of Entomology, Ain Shams University, Abbassia, Cairo 11566, Egypt.

Tel.: +202.24821633/24821096/24821031 - Ext: 711 - Fax: +202.26839622 .

Mobile: $+2.01223540005 / 01111151554$.

E-mail: mohamedkenawy85@yahoo.com

Key words: synanthropic flies, Musca domestica, distribution, seasonal abundance, Asir Province, Saudi Arabia.

Received for publication: 27 July 2014.

Revision received: 1 October 2014.

Accepted for publication: 3 October 2014.

(C)Copyright M.A. Kenawy et al., 2014

Licensee PAGEPress, Italy

Journal of Entomological and Acarological Research 2014; $46: 4623$

doi:10.4081/jear.2014.4623

This article is distributed under the terms of the Creative Commons Attribution Noncommercial License (by-nc 3.0) which permits any noncommercial use, distribution, and reproduction in any medium, provided the original author(s) and source are credited. housefly was active during the whole year with higher activities during months of low and moderate temperatures (spring, autumn and winter seasons). Analysis revealed that fly density had inverse relation with temperature.

\section{Introduction}

Synanthropic flies are those flies, which are ecologically associated with humans and are able to transmit human pathogens mechanically through this close relationship (Gabre \& Abouzied, 2003). Over 50 species of synanthropic flies have been reported to be associated with unsanitary conditions and involved in the dissemination of human pathogens in the environment (Olsen, 1998). The link between human pathogens and fly transmission is due to the fact that the adults feed on animal manure, trash, human excrement and other decaying materials; readily moving between these substrates and food, food preparation surfaces and human themselves (Chaiwong et al., 2012). Although several reports on flies in some parts of Saudi Arabia which were mainly concerned with animal myiasis (Amoudi et al., 1989; Amoudi, 1993; Eesa \& el-Sibae, 1993; Fatani \& Hilali, 1994; Alahmed, 2000; Al-Misned, 2003; Alahmed, 2004; El-Azazy \& El-Metenawy, 2004; Gad Allah \& Bosly, 2006) and few sporadic surveys in south-western Saudi Arabia (Buttiker et al., 1979; Omar \& Abdalla, 1992; Bosly, 2010) no report on fly surveys in Astir Province is available. Accordingly, the present study aimed to examine the dipterous flies associated with slaughterhouses in Asir Province in the southwest of Saudi Arabia.

\section{Materials and methods}

\section{The study area}

Asir Province $\left(19^{\circ} 00 \mathrm{~N}, 42^{\circ} 00 \mathrm{E}\right.$ to $\left.19^{\circ} 00 \mathrm{~N}, 43^{\circ} 00 \mathrm{E}\right)$ is located in the southwest of Saudi Arabia, has an area of $81,000 \mathrm{~km}^{2}$ and a population of 1,913,392 (2010 Census). It is a mountainous area divided into 3 distinct topographical zones: i) Sarawat Asir which is mountain range extending north-south along the coastal plains of the Red Sea and that rise to almost $3000 \mathrm{~m}$ at Jebel Sawdah near Abha the capital; ii) Asir Plateau; and iii) Tehamah Plain (Tehama) which is a narrow sandy coastal strip of lowlands at sea level. The Province receives more rainfall than the rest of the country falling in two seasons, the chief one being spring (March and April) and the second one in summer. Temperatures are very extreme. Temperature in Asir highlands is generally lower than in the other part of the Province and the rest of the kingdom as well. The coastal plain zone is generally characterized by lower rainfall, high temperature and relative humidity $(\mathrm{RH})$. 
The study included 11 slaughterhouses in 8 localities representing different altitudes (Figure 1). For each of the sampling site, longitude, latitude and altitude were computed using the global positioning system (Table 1).

\section{Collection of flies}

Flies were surveyed twice a month from December 2008 to November 2009 in four localities (Abha, Bisha, Muhayil and Tanomah) and 2 times a year (February and August 2009) in Rejal Almaa, Belqarn, Tathleeth and Al Barak. The Final Flight Fly Traps (Figure 2) were used in conjunction with the Final Flight Fly Lure and 1-3 drops of liquid dish detergent. The traps were suspended about one meter above the ground. Two to four traps were used depending on the area of slaughterhouse. Traps were left in site for one day and flies were collected next day. The collected flies were counted and identified by using different keys (Sabrosky, 1951; Shaumar \& Mohamed, 1983; Shaumar et al., 1985, 1989; Pape, 1998).

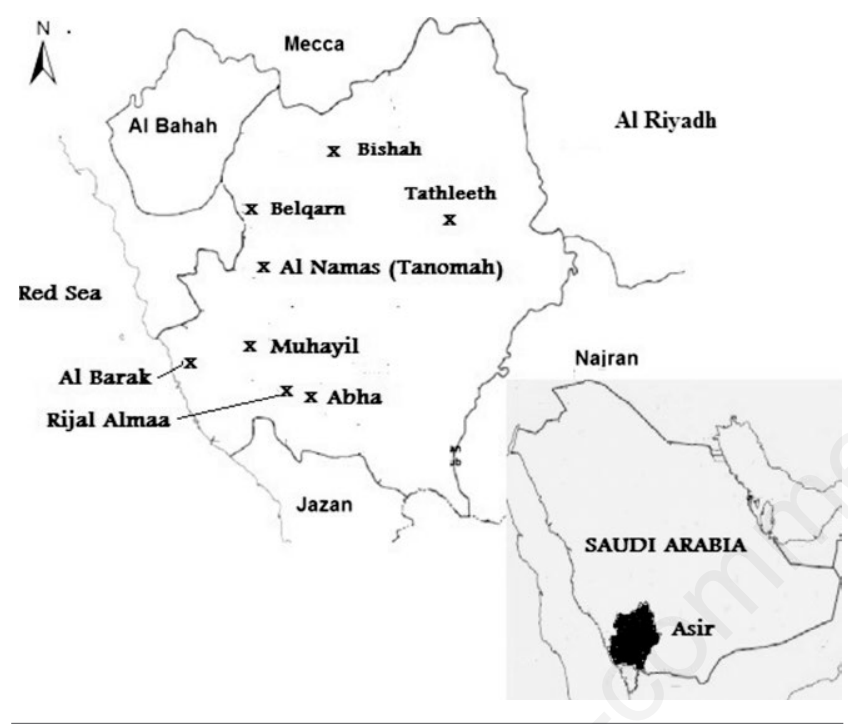

Figure 1. Distribution of surveyed localities within Asir Province.

\section{Statistical analysis}

The diversity of the fly species based on the Simpson (1-D) and Shannon (H) indices was examined at different altitudes. The Shannon indices were compared by a t-test. The seasonal abundance of the predominant species (the house fly, Musca domestica) was examined along the different altitudes (low, moderate and high) by calculating the monthly density (number of flies collected per single trap). Means and standard errors were calculated and compared by the oneway analysis of variance (ANOVA). If the ANOVA showed significant differences of the means at $\mathrm{P}=5 \%$, they were exposed to pairwise comparisons based on Tukey's honestly significant difference (HSD) test. The multiple regression analysis was applied to examine the relation of the house fly density to the temperature, $\mathrm{RH}$, wind velocity and altitude of the surveyed locality. The slopes (regression coefficients) of the regression equations were tested for deviation from zero by t-test. The PAST (Paleontological Statistics Version 2.08; Hammer et al., 2001) computerized software was used for statistical analysis.

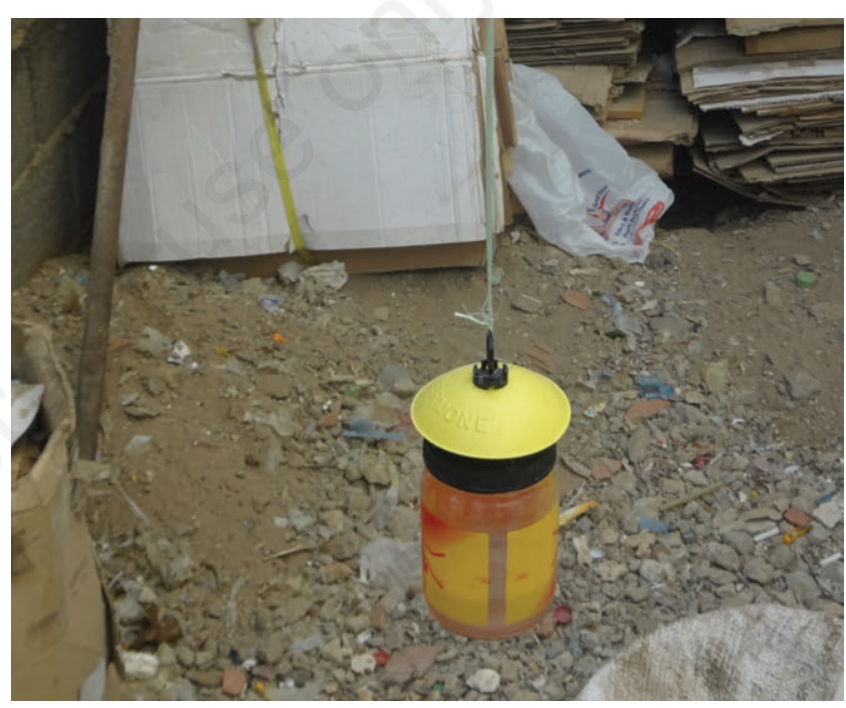

Figure 2. The Final Flight Fly Trap.

Table 1. Global positioning system data of the surveyed slaughter houses in Asir.

\begin{tabular}{|c|c|c|c|c|}
\hline \multirow[t]{3}{*}{ Locality } & \multirow[t]{3}{*}{ Slaughter house } & \multicolumn{3}{|c|}{ GPS data } \\
\hline & & \multirow[t]{2}{*}{ Altitude (m) } & \multicolumn{2}{|c|}{ Coordinates } \\
\hline & & & $\mathbf{N}$ & $\mathrm{E}$ \\
\hline Abha & Municipality & 2192 & $18^{\circ} 14^{\prime} 460^{\prime \prime}$ & $42^{\circ} 31^{\prime} 767^{\prime}$ \\
\hline \multirow[t]{2}{*}{ Bishah } & Municipality & 1211 & $20^{\circ} 58^{\prime} 436^{\prime \prime}$ & $42^{\circ} 09^{\prime} 186^{\prime}$ \\
\hline & Private & 1172 & $20^{\circ} 58^{\prime} 546^{\prime \prime}$ & $42^{\circ} 36^{\prime} 115$ \\
\hline Muhaiyl & Municipality & 456 & $18^{\circ} 34^{\prime} 760^{\prime \prime}$ & $42^{\circ} 02^{\prime} 151^{\prime}$ \\
\hline Tanomah & Municipality & 2148 & $18^{\circ} 55^{\prime} 524^{\prime \prime}$ & $42^{\circ} 13^{\prime} 307^{\prime}$ \\
\hline \multirow[t]{2}{*}{ Rejal Almaa } & Private & 1163 & $18^{\circ} 14^{\prime} 608^{\prime \prime}$ & $42^{\circ} 16^{\prime} 500^{\prime}$ \\
\hline & Municipality & 1155 & $18^{\circ} 14^{\prime} 590^{\prime \prime}$ & $42^{\circ} 16^{\prime} 538^{\prime \prime}$ \\
\hline Al Barak & Private & 25 & $18^{\circ} 13^{\prime} 033^{\prime \prime}$ & $42^{\circ} 32^{\prime} 179^{\prime}$ \\
\hline Balqarn & Municipality & 2027 & 19³3’763" & $41^{\circ} 56^{\prime} 954^{\prime}$ \\
\hline \multirow[t]{2}{*}{ Tasleeth } & Municipality & 1146 & $19^{\circ} 14^{\prime} 587^{\prime \prime}$ & $43^{\circ} 16^{\prime} 541^{\prime}$ \\
\hline & Municipality & 1106 & $19^{\circ} 13^{\prime} 825^{\prime \prime}$ & $43^{\circ} 31^{\prime} 456^{\prime \prime}$ \\
\hline
\end{tabular}

\footnotetext{
GPS, global positioning system.
} 


\section{Results}

\section{Species composition and relative abundance}

A total of 19 fly species belonging to 9 families (Table 2) were identified. Of the 11,737 collected flies, those of family Muscidae were predominating $(11,136,94.88 \%)$ followed by those of family Calliphoride (366, 3.12\%), family Sarcophagidae (143, 1.22\%) and family Fanniidae (64, 0.55\%). The other 5 families were Phoridae $(9,0.08 \%)$, Lonchaeidae $(7,0.06 \%)$, Oestridae $(5,0.04 \%)$, Ulidiidae $(4,0.03 \%)$ and Piophilidae $(3,0.03 \%)$. Of the identified species, M. domestics was predominating $(94.26 \%)$ followed by $L$. sericata $(1.51 \%)$ and $S$. carnaria (1.01\%), C. albiceps (0.67\%), F. canicularis $(0.55 \%)$, C. marginalis $(0.54 \%)$, and M. stabulans $(0.52 \%)$. The other 10 species totally represented $0.38 \%$.

\section{Spatial distribution}

Flies were represented by a higher number of species in highlands (16 spp., 84.21\%) than in the moderately altitude areas (15 spp., $78.95 \%$ ) or lowlands (13 spp., $68.42 \%$ ). They were also more abundant in highlands ( 36.45 fly/trap) than in the moderately altitude areas (35.65 fly/trap) or lowlands (28.69 fly/trap) (Table 3). The distribution of the different species varied with altitude. Although most of species (10 spp., 52.63\%) were distributed in all altitudes, only Parasarcophaga ruficornis was reported only from moderate altitude and 3 species (Ophyra sp., Chrysomya rufifacies and Oestrus ovis, 15.79\%) were reported only from highlands. Other species were reported in low and moderate altitude (Atherigona sp. and Lonchaea sp., 10.53\%), others in low and high altitudes (Piophila casei, 5.26\%) and in moderate and high altitudes (Megaselia sclaris and Physiphora demandala, 10.53\%).

\section{Species diversity}

The diversity for the fly species sampled during the year in all localities was examined (Figure 3 ). The results revealed maximum diversity in high altitudes with the highest Simpson index (1-D=0.18) and Shannon index $(\mathrm{H}=0.49, \mathrm{P}<0.001)$. On the other hand, moderate altitudes represented the sites with the minimum diversity indices (1$\mathrm{D}=0.04$ and $\mathrm{H}=0.14, \mathrm{P}<0.001)$. The low altitude localities exhibited intermediate values $(1-\mathrm{D}=0.14$ and $\mathrm{H}=0.39, \mathrm{P}<0.001)$.

\section{Studies on Musca domestica}

The monthly density showed significant differences $\left(\mathrm{F}_{2,33}=3.60\right.$, $\mathrm{P}<0.05$ ) among the different altitudes. Comparison by the Tukey's HSD indicated that higher density was in the highlands than in the moderately altitude areas or lowlands $(\mathrm{P}<0.05)$.

Regression analysis revealed that fly density had inverse relation with wind velocity $(\mathrm{b}=-0.24, \mathrm{P}<0.05)$ and temperature $(\mathrm{b}=-0.19$, $\mathrm{P}<0.05)$ and direct relation with $\mathrm{RH}(\mathrm{b}=0.06, \mathrm{P}<0.05)$ and altitude $(\mathrm{b}=0.04, \mathrm{P}<0.05)$.

In all altitude levels, flies were active during the whole year (Figure 4). In low altitudes, flies were with bimodal curve of abundance, higher activities during spring and autumn and with peaks during March

Table 2. Species composition and relative abundance of collected fly species.

\begin{tabular}{|c|c|c|c|}
\hline Family & Species & Total No. & $\%$ \\
\hline Muscidae & $\begin{array}{l}\text { Musca domestica domestica L. } \\
\text { Muscina stabulans (Fallén) } \\
\text { Atherigona sp. } \\
\text { Ophyra sp. }\end{array}$ & $\begin{array}{c}11,063 \\
65 \\
3 \\
5\end{array}$ & $\begin{array}{l}94.26 \\
0.52 \\
0.03 \\
0.04\end{array}$ \\
\hline Calliphoride & $\begin{array}{c}\text { Calliphora vicina Robineau-Desvoidy } \\
\text { Chrysomya marginalis (Wiedemann) } \\
\text { Chrysomya rufifacies Macquart } \\
\text { Chrysomya albiceps (Wiedemann) } \\
\text { Lucelia (=Phaenicia) sericata (Meigen) }\end{array}$ & $\begin{array}{c}46 \\
63 \\
1 \\
79 \\
177 \\
\end{array}$ & $\begin{array}{l}0.39 \\
0.54 \\
0.01 \\
0.67 \\
1.51\end{array}$ \\
\hline Sarcophagidae & $\begin{array}{c}\text { Sarcophaga carnaria (L.) } \\
\text { Parasarcophaga (Liopygia) ruficornis (F.) } \\
\text { Wohlfahrtia nuba (Wiedemann) } \\
\text { Bercaea cruentata (Meigen) }\end{array}$ & $\begin{array}{c}119 \\
1 \\
17 \\
6\end{array}$ & $\begin{array}{l}1.01 \\
0.01 \\
0.14 \\
0.05\end{array}$ \\
\hline Fanniidae & Fannia canicularis (L.) & 64 & 0.55 \\
\hline Piophilidae & Piophila casei (L.) & 3 & 0.03 \\
\hline Oestridae & Oestrus ovis (L.) & 5 & 0.04 \\
\hline Phoridae & Megaselia scalaris (Loew) & 9 & 0.08 \\
\hline Ulidiidae & Physiphora demandala F. & 4 & 0.03 \\
\hline Lonchaeidae & Lonchaea sp. & 7 & 0.06 \\
\hline Total & & 11,737 & \\
\hline
\end{tabular}

Table 3. Distribution and abundance of fly species along different altitudes.

\begin{tabular}{lccccc} 
Altitude & Locality & No. species (\%) & Total flies & No. traps & Fly/trap \\
Lowlands $(<500 \mathrm{~m})$ & Al Barak \& Muhayil & $13(68.42)$ & 2008 & 70 & 28.69 \\
Moderate altitude $(1106-1211 \mathrm{~m})$ & Bishah, Rejal Almaa \& Tathleth & $15(78.95)$ & 4991 & 140 & 35.65 \\
\hline Highlands $(2148-2192 \mathrm{~m})$ & Abha, Tanomah, Balqarn & $16(84.21)$ & 4738 & 130 & 36.45 \\
\hline
\end{tabular}


(mean=39.37 fly/trap) and 0ctober (mean=61.67 fly/trap). In moderate altitudes higher activities were during winter and autumn with peaks during January (mean=90.43 fly/trap) and October (mean=90.83 fly/trap). In high altitude, flies were more active from March to May (spring) with peaks during April (mean=90.44 fly/trap).

\section{Discussion and conclusions}

Although Dipterous flies are the most important arthropod vectors of animal/human diseases (Graczyk et al., 2001; Williams, 2009), no information on the occurrence of these flies in Asir Province is available. Accordingly, the aim of present study was to analyse the dipterous flies associated with slaughterhouses in Asir. The present study documented the presence of 19 species belonging to 9 families with the family of Muscidae predominating ( $\mathrm{ca} 95 \%$ ). The only available report from Asir is the report of the tumbu fly, Cordylobia anthropophaga Blanchard (F. Calliphoridae) (Omar \& Abdalla, 1992). In the adjacent Province Jazan, Musca domestica, M. domestica calleva, M. sorbens, M. lucidula, Chrysomya albiceps, C. marginalis, Sarcophaga ruficornis, S. dux, Wohlfahrtia indigens, Physiphora alceae, Anatrichus erinaceus, Coproica vagans and Oestrus ovis from farms and slaughter houses were collected (Bosly, 2010, 2013). In other parts of the Kingdom (Ryiadh, Al-Ahsa, Hail and Buraydah Provinces), the following species were reported: Megaselia scalaris, Chrysomya bezziana, C. albiceps, $C$. rufifacies, Wohlfahrtia nuba, the cluster fly Pollenia rudis (F. Calliphoridae), Oestrus ovis, Cephalopina titillator (F. Oestridae). Musca domestica, Muscina stabulans, Sarcophaga haemorrhoidalis, and Stomoxys calcitrans (Amoudi et al., 1989; Eesa \& el-Sibae, 1993; Fatani \& Hilali, 1994; Alahmed, 2000, 2004; Al-Misned, 2003; Albarrak, 2009).

Among the identified species, $M$. domestica was predominating (94\%). The numerical dominance of $M$. domestica was previously observed in Buraydah, where flies represented $75-98 \%$ of the total synanthropic fly population (Eesa \& el-Sibae, 1993). It was suggested (Bunchu et al., 2008) that sanitation can have a significant impact on the availability of food and breeding places for synanthropic flies, thus affecting fly population densities in a particular human habitation. Poor sanitation practices may therefore increase the potential numbers of synanthropic flies (Bosly, 2010).

Flies altogether were more common ( $84 \%$ of reported species) and abundant ( 36 fly/trap) in highlands than in the moderately altitude areas or lowlands. The highlands were found with the highest diversi- ty indices $(1-\mathrm{D}=0.18$ and $\mathrm{H}=0.49, \mathrm{P}<0.001)$ due to the high richness of the species in these localities ( $n=16 / 19 \mathrm{spp}$.). This may indicate that the highlands are the most favourable sites for breeding and activity of flies. Bosly (2010) showed that there is a relation between the number of recorded flies and elevation of the Jazan Province, but intensive ecological studies are required to give an appropriate interpretation for this observation. Likewise, the highest density of $M$. domestica was in the highlands ( 58 fly/trap, $\mathrm{P}<0.05$ ) than in the other altitudes. This has been supported by regression analysis, which revealed that house fly density was directly related to the altitude level $(\mathrm{P}<0.05)$.

In all altitude levels, house fly was active during the whole year with higher activities during spring, autumn and winter seasons with peaks during January, March, and October (low and moderate altitudes) and spring with a peak during April (high altitude), i.e. flies were more active during months of low and moderate temperatures (mean=20$30^{\circ} \mathrm{C}$ ) than during the hot months (mean $=39^{\circ} \mathrm{C}$ ). Almost similar observations were obtained by Bosly (2010) in Jazan where flies were more abundant at the coldest months (January and February) and the least number of flies was recorded at the hottest month (June). However, in Buraydah, northern of Saudi Arabia, flies were collected throughout the year and reached their maximum abundance in May and minimum occurrence in January (Eesa \& el-Sibae, 1993). Albarrak (2009) at Hail Province, northern Saudi Arabia studied the seasonal abundance of house fly in out-door and indoor farms of cattle, sheep, camel, and poultry. In both indoor and outdoor farms, flies recorded the least numbers in January, February and March while recorded the highest numbers in September or October.

Regression analysis revealed that house fly density had inverse relation with temperature and direct relation with $\mathrm{RH}(\mathrm{P}<0.05)$. Jin \& Jaal (2009) in poultry farms in Penang, Malaysia observed that the occurrence of flies showed strong correlation indices with relative humidity $(\mathrm{r}=0.803, \mathrm{P}<0.05)$ while temperature had no significant effect on the abundance of flies. Such inverse relation to temperature as observed in this study may be related to the adverse effects of high temperature on adult survival which can explain this result.

Numerous members of the synanthropic flies mainly belonging to the family Calliphoridae are carrion-breeding flies that have veterinary, medical and forensic importance. Some species are myiasis producers (Zumpt, 1965), while others are known vectors of several enteric diseases (Sulaiman et al., 1988). Other carrion-breeding species may be used by forensic entomologists to detect the post-mortem interval (Smith, 1986; Catts \& Goff, 1992).

In Saudi Arabia, several authors reported cases of human/animal

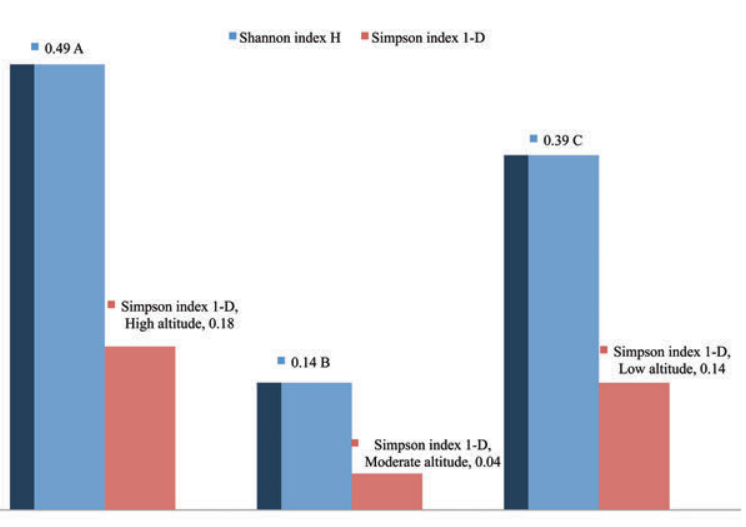

Figure 3. Diversity indices of the collected fly species in Asir.

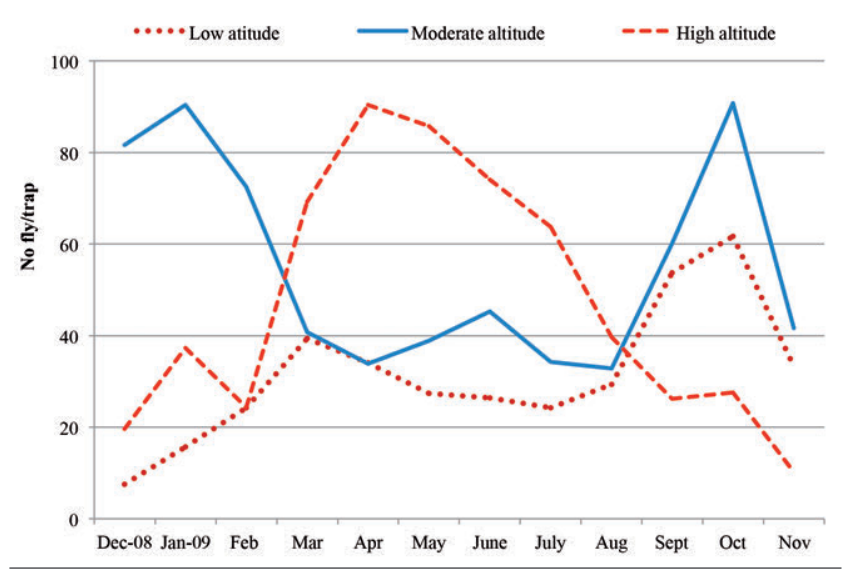

Figure 4. Seasonal abundance of Musca domestica at different altitudes. 
myiasis. Omar \& Abdalla (1992) reported seven cases of human cutaneous myiasis from Asir Province caused by maggots of the tumbu fly, Cordylobia anthropophaga which confirms that this Calliphorinae species is not restricted to the tropical Africa. Other reported forms of human myiasis were urinary myiasis caused by Megaselia scalaris in a 5-year-old Saudi girl (Wakid, 2008), wound myiasis with Sarcophaga sp. as a vector in Makkah city (Zaglool et al., 2013) and a case of ophthalmomyiasis caused by $1^{\text {st }}$ instar larvae of Oestrus ovis (Kenawy, unpublished data, 1997). Animal myiasis were observed: i) in camels slaughtered at Al-Ahsa abattoir, Eastern Province, infested with second and third instars of Cephalopina titillator (F. Oestridae) (Fatani \& Hilali, 1994); ii) in sheep infested with Oestrus ovis larvae both in Riyadh abattoir (Alahmed, 2000) and in Jazan (Bosly, 2013) and infested with Chrysomya bezziana, C. albiceps, and Wohlfahrtia nuba in Riyadh (Alahmed, 2004).

It was reported that maggots of Chrysomya villeneuvi, C. albiceps, $C$. marginali, $C$. inclinata, $C$. putoria, C. megacephala. C. chloropyga and Calliphora croceipalpis are of importance as entomological evidence in the forensic investigation of many human death cases, particularly when estimating the time elapsed since death or the post-mortem interval (Smith, 1986; Goff, 1993; Byrd \& Castner, 2001; Sukontason et al., 2003). However there are no reports from Saudi Arabia and from any other Arab countries about the use of insects in forensic investigations. In recent years, this becomes more common in police investigations in Europe and in USA (Benecke, 2001).

In conclusion, the occurrence of numerous species of synanthropic flies in Asir with their medical/veterinary importance as myiasis producers, carrion-breeders and filth flies may be of thread to human and animal health and necessitates a wide sanitary and control programs.

\section{References}

ALAHMED A.M., 2000 - Seasonal infestation of Oestrus ovis larvae in sheep heads in central Province of Saudi Arabia. - J. Egypt Soc. Parasitol. 30: 895-901.

ALAHMED A.M., 2004 - Myiasis in sheep farms in Riyadh Province, Saudi Arabia. - J. Egypt. Soc. Parasitol. 34: 153-60.

ALBARRAK A.S., 2009 - Comparative studies on house fly, Musca domestica l., population in different animal farms in relation to attractants and control at Hail Province, Saudi Arabia. - Pak. Entomol. 31: 142-147.

AL-MISNED F.A., 2003 - New record of cluster fly Pollenia rudis (F.) with distribution of all known blow flies (Diptera: Calliphoridae) of Saudi Arabia. - J. Egypt. Soc. Parasitol. 33: 1-12.

AMOUDI M.D., 1993 - Effect of temperature on the developmental stages of Wohlfahrtia nuba (Diptera: Sarcphagidae). - J. Egypt. Soc. Parasitol. 23: 697-705.

AMOUDI M.D., DIAB F.M., ABU-FANNAH S.S., 1989 - The occurrence of Megaselia scalaris (Loew) (Diptera: Phoridae) in Saudi Arabia with some aspects on the life history and distribution in Ryiadh Province. - J. K. Saud Univ. Sci. 1-2: 43-51.

BENECKE M., 2001 - A brief history of forensic entomology. - Forensic Sci. Int. 120: 2-14.

BOSLY H.A., 2010 - Prevalence of dipterous flies with veterinary importance in selected sheep's farms and slaughter houses in Jazan, Saudi Arabia. - Egypt. Acad. J. Biol. Sci. A. Entomol. 3: 63-73.

BOSLY H.A., 2013 - Seasonal prevalence of Oestrus ovis L. (Diptera: Oestridae) larvae in infested sheep in Jazan Province, Saudi Arabia. - J. Parasitol. Vector Biol. 5: 66-71.

BUNCHU N., SUKONTASON K. L., OLSON J. K., KURAHASHI H., SUKONTASON K., 2008 - Behavioral responses of Chrysomya megacephala to natural products. - J. Parasitol. Res. 102: 419-429.
BUTTIKER W., ATTIAH M.A., PONT A., 1979 - Synanthropic Flies. Fauna Saudi Arabia 1: 352-366.

BYRD J.H., CASTNER J.L., 2001 - Insects of forensic importance. In: BYRD J.H., CASTNER J.L. (Eds.), Forensic entomology: the utility of arthropods in legal investigations. CRC Press, Boca Raton, FL: 43-79.

CATTS E.P., GOFF M.L., 1992 - Forensic entomology in criminal investigations. - Annu. Rev. Entomol. 37: 253-272.

CHAIWONG T., SRIVORAMAS T., SUKONTASON K., SANFORD R.M., MOOPHAYAK K., SUKONTASON L.K., 2012 - Survey of the synanthropic flies associated with human habitations in Ubon Ratchathani Province of Northeast Thailand. - J. Parasitol. Res. 2012: 613132.

EESA N.M., EL-SIBAE M.M., 1993 - Population dynamics of some synanthropic fly species in different habitats in Buraydah, Saudi Arabia. - J. Egypt. Soc. Parasitol. 23: 133-140.

EL-AZAZY 0.M., EL-METENAWY T.M., 2004 - Cutaneous myiasis in Saudi Arabia. - Vet. Rec. 154: 305-306.

FATANI A., HILALI M., 1994 - Prevalence and monthly variations of the second and third instars of Cephalopina titillator (Diptera: Oestridae) infesting camels (Camelus dromedarius) in the Eastern Province of Saudi Arabia. - Vet Parasitol. 53: 145-151.

GABRE R.M., ABOUZIED E.M., 2003 - Sarcophagous flies in Suez Province, Egypt II- Synanthropic and abundance degrees. - Bull. Soc. Entomol. Egypt. 80: 125-132.

GAD ALLAH N., BOSLY H., 2006 - Diptera associated with camels in the Jeddah Province, western Saudi Arabia. Fauna Arabia 21: 339-250.

GOFF M.L., 1993 - Estimation of the postmortem interval using arthropod development and successional patterns. - Forensic. Sci. Rev. 5: 81-94.

GRACZYK T.K., KNIGHT R., GILMAN R.H., CRANFIELD M.R., 2001. - The role of non-biting flies in the epidemiology of human infectious diseases. - Microbes Infect. 3: 231-235.

HAMMER Ø., HARPER D.A.T., RYAN P.D., 2001 - Past: Paleontological statistics software package for education and data analysis. Available from: http://www.nhm.uio.no/norlex/past/download.html

JIN B.L., JAAL Z., 2009 - Temporal changes in the abundance of Musca domestica Linn (Diptera: Muscidae) in poultry farms in Penang, Malaysia. - Trop. Biomed. 26: 140-148.

OLSEN A.R., 1998 - Regulatory action criteria for filth and other extraneous materials. III. Review of flies and food borne enteric disease. - Regul. Toxicol. Pharm. 28: 199-211.

OMAR M.S., ABDALLA R.E., 1992. - Cutaneous myiasis caused by tumbu fly larvae, Cordylobia anthropophaga in southwestern Saudi Arabia. - Trop. Med. Parasitol. 43: 128-129.

PAPE T., 1998. - Sarcophagidae. In: PAPP L., DARVAS B. (Eds.), Contributions to a manual of Palaearctic/European Diptera. Science Herald, Budapest: 649-678.

SABROSKY C., 1951. - Chloropidae. - Bull. Br. Mus. (Nat Hist) 2: 711-828.

SHAUMAR N., MOHAMMED S., 1983. - Keys for identification of species of Family Sarcophagidae (Diptera) in Egypt. - Bull. Soc. Entomol. Egypt. 64:121-132.

SHAUMAR N.F., MOHAMMED S.K., MOHAMMED S.A., 1989. - Keys for identification of species of family Calliphoridae (Diptera) in Egypt. - J. Egypt. Soc. Parasitol. 19: 669-681.

SHAUMAR N.F., MOHAMMED S.K., SHOUKRY I.F., 1985. - Flies of subfamily Muscinae (Muscidae-Diptera) in Egypt. - J. Egypt. Soc. Parasitol. 15: 513-523.

SMITH K.G.V., 1986 - A manual of forensic entomology. - British Museum of Natural History, Cornell University Press, London and Ithaca, NY.

SUKONTASON K., SUKONTASO K.L., PIANGJA S., CHAIWON T., BOONCH N., KURAHASH H., 2003 - Hairy Maggot of Chrysomya villeneuvi (Diptera: Calliphoridae), a fly species of forensic importance. - J. Med. Entomol. 40: 983-984. 
SULAIMAN S., SOHADI A.R., YURMS H., IBERAHIM R., 1988 - The role of some cyclorrhaphan flies as carriers of human helminths in Malaysia. - Med. Vet. Entomol. 2: 1-6.

WAKID M.H., 2008 - A laboratory-based study for first documented case of urinary myiasis caused by larvae of Megaselia scalaris (Diptera: Phoridae) in Saudi Arabia. - Korean J. Parasitol. 46: 33-36.

WILLIAMS R., 2009 - Veterinary entomology: livestock and com- panion animals. - Purdue University, West Lafayette, IN. ZAGLOOL D.A.M., TAYEB K., KHODARI Y.A.W., FAR00Q M.U., 2013 First case report of human myiasis with Sarcophaga species in Makkah city in the wound of a diabetic patient. - J. Nat. Sci. Biol. Med. 4: 225-228.

ZUMPT F., 1965 - Myiasis in man and animals in the old world. Butterworth and Co. Ltd., London. 